\title{
PENERAPAN SISTEM GADAI EMAS PADA PT. PEGADAIAN SYARIAH KANTOR CABANG KOTA PROBOLINGGO
}

\author{
Maula Nasrifah $^{1}$, Siti Chusnul ${ }^{2}$ \\ ${ }^{1}$ Universitas Islam Zainul Hasan Genggong \\ Jl. PB. Sudirman No. 360 Semampir Kraksaan Probolinggo \\ ${ }^{2}$ Universitas Islam Zainul Hasan Genggong \\ Jl. PB. Sudirman No. 360 Semampir Kraksaan Probolinggo \\ ${ }^{1}$ maulanasrifah78@gmail.com \\ ${ }^{2}$ chusnul78@gmail.com
}

\begin{abstract}
Gadai Emas is the provision of funds to customers using pawn financing that can meet the financial needs of customers by using gold as collateral for financing. This study aims to describe the application of the Gold Pawn System at PT. Pegadaian Syariah probolinggo branch office as well as describe the constraints faced by PT. Pegadaian Syariah Probolinggo Branch Office is in the process of being implemented.

This research is a field research, which is descriptive qualitative by conducting in-depth interviews with PT. Pegadaian Syariah, the data is then analyzed and produces conclusions.

From the results of the study, it can be explained that in its application it has implemented easy steps but still in accordance with existing operational standards, including; through the stages of submitting financing, stages of estimating gold as collateral, stages of disbursement of financing funds, stages at maturity and stages at the time of repayment. Meanwhile, the obstacles that are often faced are due to difficulties in communicating with customers who cannot make payments and face complaints from customers on collateral items.
\end{abstract}

Keywords: Gold Pawn, Customers, and PT. Sharia Pawnshop

\begin{abstract}
ABSTRAK
Gadai Emas merupakan pemberian dana kepada nasabah dengan menggunakan pembiayaan gadai yang dapat memenuhi kebutuhan keuangan nasabah dengan menggunakan emas sebagai jaminan atas pembiayaan. Penelitian ini bertujuan untuk mendeskripsikan penerapan Sistem Gadai Emas pada PT. Pegadaian Syariah kantor cabang probolinggo sekaligus mendeskripsikan kendala-kendala yang dihadapi PT. Pegadaian Syariah Kantor Cabang Probolinggo didalam proses penerapannya.

Penelitian ini merupakan penelitian lapangan, yang bersifat deskriptif kualitatif dengan melakukan wawancara secara mendalam kepada pihak PT. Pegadaian Syariah, data tersebut kemudian dianalisis dan menghasilkan kesimpulan.

Dari hasil penelitian dapat dijelaskan bahwa pada penerapannya sudah menerapkan tahapantahapan yang mudah namun tetap sesuai dengan standar operasional yang ada, diantaranya; melalui tahapan pengajuan pembiayaan, tahapan penaksiran emas sebagai barang jaminan, tahapan pencairan dana pembiayaan, tahapan pada saat jatuh tempo dan tahapan-tahapan pada saat pelunasan. Sedangkan kendalakendala yang sering dihadapi karena kesulitan berkomuniasi dengan nasabah yang tidak dapat melakukan pelunasan dan menghadapi komplain dari nasabah atas barang jaminan.
\end{abstract}

Kata Kunci: Gadai Emas, Nasabah, dan PT. Pegadaian Syariah 


\section{PENDAHULUAN}

Lembaga keuangan merupakan sebuah lembaga yang berfungsi sebagai intermediasi dengan menghimpun dana dari masyarakat yang kelebihan dana dan menyalurkannya kembali kepada masyarakat yang kekurangan agar terwujud masyarakat yang adil makmur, dan sejahtera. ${ }^{1}$ Salah satu lembaga keuangan yang ada di Indonesia adalah pegadaian.

Pada masa pemerintah RI, dinas pegadaian merupakan kelanjutan dari Pemerintah Hindia Belanda, status pegadaian diubah menjadi Perusahaan Negara (PN) Pegadaian berdasarkan UU No.19 Prp.1960 jo. Kemudian berdasarkan Peraturan Pemerintah RI No. 7 Tahun 1969 tanggal 11 Maret 1969 tentang Perubahan Kedudukan PN Pegadaian menjadi Jawatan Pegadaian jo. UU No. 9 Tahun 1969 tanggal 1 Agustus 1969. Selanjutnya untuk meningkatkan efektivitas dan produktivitasnya, bentuk Perusahaan Jawatan Pegadaian dialihkan menjadi Perusahaan Umum Pegadaian berdasarkan Peratutan Pemerintah No. 10 Tahun 1990 tanggal 10 April 1990. ${ }^{2}$

Terbitnya Peraturan Pemerintah Nomor 10 Tahun 1990 tanggal 1 April 1990 dapat dikatakan menjadi tonggak awal kebangkitan pegadaian. Peraturan Pemerintah Nomor 10 Tahun 1990 menegaskan misi yang harus diemban oleh pegadaian untuk mencegah praktik riba, dimana misi ini tidak berubah hingga terbitnya Peraturan Pemerintah (PP) Nomor.103 Tahun 2000 yang dijadikan landasan kegiatan usaha Perum pegadaian sampai sekarang. ${ }^{3}$ Adapun istilah riba yaitu pengambilan tambahan dari harta pokok atau modal secara bathil baik dalam transaksi jual beli maupun pinjam meminjam atau yang bertentangan dengan prinsip muamalah dalam Islam. Riba bisa melalui transaksi jual beli, utang piutang, tukar menukar barang sejenis dengan kuantitas yang tidak sama, dan sebagainya. ${ }^{4}$

Saat ini, pegadaian merupakan lembaga formal di Indonesia yang berdasarkan hukum dibolehkan melakukan pembiayaan dengan bentuk penyaluran kredit atas dasar hukum gadai. Tugas pokok Pegadaian adalah menjembatani kebutuhan dana masyarakat dengan pemberian uang pinjaman berdasarkan hukum gadai. Pegadaian Syariah hadir di Indonesia dengan membentuk unit gadai syariah di beberapa kota di Indonesia yang mulai beroperasi sejak 2003. Pegadaian syariah dalam menjalankan operasionalnya berpegang kepada prinsip syariah. Payung hukum gadai syariah berpegang pada Fatwa DSN MUI No. 25/DSN-MUI/III/2002 tanggal 26 juni 2002 tentang rahn yang menyatakan bahwa pinjaman dengan menggadaikan barang jaminan utang dalam bentuk rahn diperbolehkan, dan fatwa DSN MUI No. 26/DSN MUI/III/2002 tentang gadai emas. ${ }^{5}$

\footnotetext{
${ }^{1}$ Kasmir, Manajemen Perbankan, (Jakarta:Raja Grafindo Persada, 2003), 3.

2 Andri Soemitra, Bank dan Lembaga Keuangan Syariah, (Jakarta: Kencana, 2009),

${ }^{3}$ Yusnedi Achmad, Gadai Syariah, (Yogyakarta : Deepublish, 2015), h. 11.

4 . Isnaini Harahap, Marliyah, dkk, Hadis-Hadis Ekonomi, (Jakarta: Prenada media Group, 2015), h. 189.

${ }^{5}$ Ibid, Bank dan Lembangan Keuangan Syariah, h 400
} 
Gadai merupakan jaminan yang diserahkan oleh pihak pengutang kepada yang memberi utang. Pemberi hutang mempunyai kuasa penuh untuk menjual barang jaminan tersebut, apabila pihak pengutang tidak mampu lagi membayar hutangnya pada saat jatuh tempo.Barang jaminan tetap milik orang yang menggadaikan (orang yang berutang) tetapi dikuasai oleh penerima gadai (yang berpiutang). Praktik seperti ini telah ada sejak zaman Rasulullah SAW, dan Rasulullah sendiri pernah melakukannya.Gadai mempunyai nilai sosial yang sangat tinggi dan dilakukan secara sukarela atas dasar tolong menolong. ${ }^{6}$

Seperti kita ketahui, emas merupakan komoditas yang sangat berharga dan sangat likuid yang sewaktu-waktu bisa ditukarkan dengan uang dalam waktu yang cepat.Emas mudah diperjualbelikan dan sifatnya universal sehingga dihargai dimanapun.Sudah ada kesepakatan budaya secara global bahwa emas adalah logam mulia dengan nilai estesis yang tinggi.Nilai keindahannya berpadu dengan harganya yang menarik sehingga jadilah emas sebagai sarana untuk mengekspresi diri. $^{7}$

Gadai emas merupakan produk pembiayaan atas dasar jaminan berupa emas sebagai salah satu alternatif memperoleh pembiayaan secara cepat. Pinjaman gadai emas merupakan fasilitas pinjaman tanpa imbalan dengan jaminan emas dengan kewajiban pinjaman secara cicilan dalam jangka waktu tertentu. ${ }^{8}$ Di dalam pembiayaan gadai emas syariah (rahn) dilakukan oleh Rahin (pemilik barang) dan Al-Murtahin (penerima barang) dengan tujuan untuk memenuhi kebutuhannya bagi pemilik barang dengan menggadaikan barang tersebut sesuai prinsip syariah.Pembiayaan gadai emas syariah ( $r a h n)$ memiliki prosedur yang dilalui hingga barang gadai tersebut kembali dimiliki oleh pemiliknya atau tidak. Dalam gadai syariah, yang terpenting adalah dapat memberikan kemaslahatan sesuai dengan diharapkan masyarakat dan menjauhkan diri dari praktik-praktik riba, qimar (spekulasi), maupun gharar (ketidak transfaranan) yang berakibat terjadinya ketidakadilan dan kedzahliman pada masyarakat dan nasabah. ${ }^{9}$

Menurut konsep rahn, barang yang berharga digunankan untuk menjamin hutang yang dapat digunakan sebagai sumber pelunasan itu, apabila hutang tersebut pada waktunya tidak dapat dilunasi oleh orang yang berhutang.Dalam hal debitur atau orang yang berutang tidak dapat melunasi hutangnya, agunan tersebut dijual dan hasil penjualannya dipakai sebagai sumber

\footnotetext{
${ }^{6}$ Imam Mustofa, Fiqih Mu'amalah Kontemporer, (Jakarta: Rajawali Pers, 2016), h. 193.

${ }^{7}$ www.Pegadaiansyariah.co.id diakses pada tanggal 17 Januari 2019

${ }^{8}$ Ibid, Bank dan Lembaga Keuangan Syariah, h. 421.

9. Sasli Rais, Pegadaian Syariah: Konsep dan Sistem Operasional: Suatu Kajian Kontemporer, (Jakarta: UI-Press, 2005), h. 5.
} 
pelunasan.Barang jaminan itu baru dapat dijual/ dihargai apabila dalam waktu yang disetujui kedua belah pihak, hutang tidak dapat dilunasi oleh debitur. ${ }^{10}$

Dalam proses untuk mencapai tujuan, setiap organisasi perusahaan selalu dihadapkan pada hambatan dan kendala yang terjadi, baik kendala teknis maupun operasioanl. Hambatan atau kendala tersebut merupakan sebuah konsekuensi logis yang akan dihadapi sebuah organisasi ataupun perusahaan dalam mencapai tujuan. Semua hal yang dapat mengakibatkan kerugian bagi perusahaan kita kenal sebagai risiko.Setiap usaha bisnis atau pendirian perusahaan, haruslah mengukur potensi risikonya terlebih dahulu. ${ }^{11}$

Pegadaian Syariah Kantor Cabang Kota Probolinggo merupakan salah satu pegadaian syariah yang memiliki produk gadai emas. gadai meas ini dapat mempermudah nasabah didalam memenuhi kebutuhan dari data yang diperoleh pegadaian syariah kantor cabang probolinggo memilii nasabah yang

Jumlah nasabah pengguna produk gadai emas selalu meningkat. dari data yang diperoleh pada tahun 2017 jumlah nasabah 833, tahun 2018 1387, 20191940 dan pada tahun 2019 meningkat ke 2311.

\section{LANDASAN TEORI}

\section{Pengertian Rahn}

Ar-Rahn merupakan perjanjian penyerahan barang untuk menjadi agunan dari fasilitas pembayaran yang diberikan. Ada beberapa definisi yang dikemukakan oleh ulama fiqh, yaitu Ulama Mazhab Maliki mendefinisikan rahn sebagai harta yang bersifat mengikat.Ulama Mazhab Hanafi mendefinisikan rahn dengan menjadikan sesuatu (barang) sebagai jaminan terhadap hak (piutang) yang mungkin dijadikan sebagai pembayar hak (piutang) tersebut, baik seluruhnya maupun sebagiannya.

Sedangkan menurut Ulama Mazhab Syafi'i dan Mazhab Hanbali mendefinisikan rahn dalam arti akad, yaitu menjadikan materi (barang) sebagai jaminan utang yang dapat dijadikan pembayaran utang apabila orang yang berutang tidak bisa membayar utang itu.

Rahn di tangan murtahin (pemberi uang) hanya berfungsi sebagai jaminan utang dari rahin (orang yang berutang).Barang jaminan itu baru dapat dijual/dihargai apabila disetujui oleh kedua belah pihak, dimana utang tidak dapat dilunasi oleh rahin.Oleh sebab itu, hak murtahin terhadap barang jaminan hanya apabila rahin tidak melunasi utangnya.

\footnotetext{
${ }^{10}$ Sutan Remy Sjahdeini, Perbankan Syariah Produk-Produk Dan Aspek-Aspek Hukumnya, (Jakarta:Kencana, 2014), h. 364

11 Muhammad Muslich, Manajemen Risiko Operasional: Teori dan Praktik, (Jakarta: PT. Bumi Aksara, 2007$)$, h. 3.
} 
Menurut Syafi'iyah Bila marhun hilang dibawah penguasaan murtahin, maka murtahin tidak wajib menggantinya, kecuali bila rusak atau hilangnya itu karena kelalaian murtahin atau karena disia-siakan, umpamanya murtahin bermain-main dengan api, lalu terbakarnya barang gadaian itu, atau gudang tidak dikunci lalu barang-barang itu hilang dicuri orang. Pokoknya murtahin diwajibkan memelihara sebagaimana layaknya, bila tidak demikian, ketika ada cacat atau kerusakan apalagi hilang menjadi tanggung jawab murtahin.

Menurut Hanafi, murtahin yang memegang marhun menanggung risiko kerusakan marhun atau kehilangan marhun, bila marhun itu rusak atau hilang, baik karena kelalaian maupun tidak. ${ }^{12}$

Perjanjian gadai dalam Islam disebut rahn, yaitu perjanjian menahan sesuatu barang sebagai tanggungan utang.Kata rahn menurut bahasa berarti "tetap", "berlangsung", dan "menahan". Sedangkan menurut istilah berarti menjadikan sesuatu benda bernilai menurut pandangan syara' sebagai tanggungan utang, dengan adanya tanggungan utang itu seluruh atau sebagian utang dapat diterima.

Dalam buku lain juga didefinisikan bahwa rahn adalah menahan sesuatu dengan hak yang memungkinkan pengambilan manfaat darinya atau menjadikan sesuatu yang bernilai ekonomis pada pandangan syari'ah sebagai kepercayaan atas utang, yang memungkinkan pengambilan utang secara keseluruhan atau sebagian dari utang itu.

Dari berbagai definisi di atas dapat disimpulkan bahwa rahn merupakan suatu akad utangpiutang dengan menjadikan barang yang mempunyai nilai harta menurut pandangan syara' sebagai jaminan, hingga orang yang bersangkutan boleh mengambil uang. Gadai untuk menanggung semua utang. Kalau orang yang berutang mengembalikan sebagian utangnya, maka ia tidak boleh mengambil barang yang digadaikan sebelum melunasi semua utangnya.

\section{Dasar Hukum Rahn}

Dewan Syariah Nasional menetapkan aturan tentang rahn sebagaimana tercantum dalam Fatwa Dewan Syariah Nasional nomor 25/DSN-MUI/III/2002 tertanggal 26 Juni 2002 sedangkan rahn emas tercantum dalam Fatwa Dewan Syariah Nasional nomor 26/DSN-MUI/III/2002 tertanggal 28 Maret $2002^{13}$.

Rahn (gadai) hukumnya boleh berdasarkan dalil Al-Qur'an, Hadist, dan Ijma'. Dalil AlQur'an adalah firman Allah dalam QS. Al-Baqarah (2):283

\footnotetext{
${ }^{12}$ Hendi Suhendi, Fiqh Muamalah, (Jakarta: Rajawali Pers, 2011), h. 109.

${ }^{13}$ Muhammad Ridwan Basalamah dan Mohammad Rizal, Perbankan Syariah, (Jatim: Empatdua Media, 2018), h. 5051.
} 


\section{و ان كنتم علا سفر ولم تجد واكا تبا فرهان مقبوضة (ا لبقرة/) r r r}

Artinya: "Dan jika kalian berada dalam perjalanan (bermuamalah tidak secara tunai), sedangkan kalian tidak mendapatkan seorang penulis, maka hendaklah ada barang tanggungan yang dipegang." (QS. Al-Baqarah (2):283).

Kemudian dasar Hadist rahn diantaranya adalah Hadist Nabi Riwayat Al Bukhari dan Muslim yang bersumber dari Aisyah r.a:

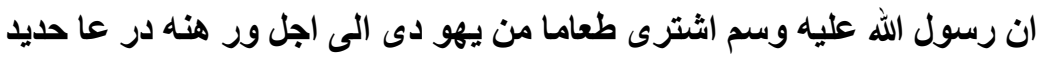

Artinya: "Bahwa Rasulullah SAW membeli makanan dari seorang Yahudi dan beliau menggadaikan baju besinya kepadanya (HR. Bukhari-Muslim).

Dasar Ijma' rahn adalah bahwa kaum Muslimin sepakat memperbolehkan rahn (gadai) secara syariat ketika berpergian (safar) dan ketika di rumah (tidak berpergian) kecuali Mujahid berpendapat rahn (gadai) hanya berlaku ketika berpergian berdasarkan dalil diatas. Akan tetapi, pendapat Mujahid ini dibantah dengan argumentasi hadist diatas. Di samping itu, penyebutan safar (berpergian) dalam ayat di atas keluar dari umum (kebiasaan). ${ }^{14}$

\section{Rukun Dan Syarat Rahn}

Rukun rahn ada empat, yaitu pemberi gadai (rahin), penerima gadai (murtahin), barang jaminan (marhun), dan utang (marhun bih).Sementara rukun rahn adalah dua pihak yang berakad, akad rahn, barang jaminan (marhun) dan utang (marhun bih). Menurut Hanafiyah rahn adalah ijab dan kabul dari rahin dan murtahin.

Dalam setiap akad, unsur dan rukunnya harus memenuhisyarat. Berkaitan dengan rahn, syarat bagi para pihak berakad sama dengan syarat dalam akad lainnya. Syarat tersebut adalah para pihak harus berakal, sudah baligh, tidak dalam paksaan atau tidak terpaksa.Pasal 330 KHES menyebutkan bahwa para pihak yang melakukan akad gadai harus sudah cakap hukum.Cakap hukum disini berarti berakal, sudah dewasa atau baligh serta tidak dalam paksaan.

Syarat yang terkait dengan utang adalah, pertama, utang adalah hak yang harus dibayar.Kedua, jumlah melebihi dari nilai barang yang menjadi jaminan.Ketiga, hak utang harus jelas.Kalangan Syafiiyah dan Hanbaliyah mensyaratkan, pertama, utang merupakan utang yang tetap dan wajib dibayar oleh rahin.Kedua, utang harus mengikat kedua belah pihak.Ketiga, jumlah, ukuran dan sifat harus jelas diantara para pihak yang berakad.

\footnotetext{
${ }^{14}$ Mardani, Fiqh Ekonomi Syariah, (Jakarta: Kencana, 2012), h. 287-289.
} 
Syarat-syarat yang terkait dengan barang yang menjadi objek jual beli adalah sebagai berikut:

a) Barang yang digadai harus benar-benar ada dan nyata.

b) Objek transaksi berupa barang yang dinilai, halal, dapat dimiliki, dapat disimpan dan dimanfaatkan sebagaimana mestinya.

c) Barang yang dijadikan objek transaksi merupakan hak milik secara sah dan kepemilikan sempurna.

d) Objek harus dapat diserah saat transaksi.

e) Selain syarat diatas ada satu syarat lagi yang mutlak yang harus terpenuhi, yaitu barang yang digadaikan harus tahan lama dan tidak mudah rusak, seperti emas, perak, logam mulia dan lain lain. ${ }^{15}$

\section{Tujuan Dan Manfaat Rahn}

Sifat usaha pegadaian pada prinsinya menyediakan layanan bagi kemanfaatan masyarakat umum dan sekaligus memupuk keuntungan berdasarkan prinsip pengolaan yang baik. Oleh karena itu, Pegadaian bertujuan sebagai berikut:

a) Turut melaksanakan dan menunjang pelaksanaan kebijaksanaan dan program pemerintah dibidang ekonomi dan pembangunan nasional, pada umumnya melalui penyaluran uang pembiayaan/pinjaman atas dasar hukum gadai.

b) Pencegahan praktik ijon, penggadaian gelap, dan pinjaman tidak wajar lainnya.

c) Pemanfaatan gadai bebas bunga pada gadai syariah memiliki efek jaring pengaman sosial karena msyarakat yang butuh dana mendesak tidak lagi dijerat pinjaman/pembiayaan berbasis bunga.

d) Membantu orang-orang yang membutuhkan pinjaman dengan syarat mudah.

\section{Adapun manfaat pegadaian antara lain:}

a) Bagi nasabah, tersedianya dana dengan prosedur yang relatif lebih sederhana dan dalam waktu yang lebih cepat dibandingkan dengan pembiayaan/ kredit perbankan. Disamping itu, nasabah juga mendapatkan manfaat penaksiran nilai suatu barang bergerak secara profesional. Fasilitas penitipan barang bergerak yang aman dan dapat dipercaya.

\footnotetext{
${ }^{15}$ Panji Adam, FATWA-FATWA EKONOMI SYARIAH: Konsep, Metodologi, dan Implementasinya pada Lembaga Keuangan Syariah, (Jakarta: Amzah, 2018), h. 283-284.
} 
b) Bagi perusahaan pegadaian

1) Penghasilan yang bersumber dari sewa tempat penyimpanan barang gadai.

2) Penghasilan yang bersumber dari ongkos yang dibayarkan oleh nasabah memperoleh jasa tertentu. Bagi bank syariah yang mengeluarkan produk gadai syariah akan mendapatkan keuntungan dari pembebanan biaya administrasi dan biaya sewa tempat penyimpanan emas.

3) Melaksanakan misi Pegadaian sebagai BUMN yang bergerak dalam bidang pembiyaan berupa pemberian bantuan kepada masyarakat yang memerlukan dana dengan prosedur yang relatif sederhana ${ }^{16}$.

\section{Risiko Rahn}

Adapun risiko yang memungkinkan terdapat pada rahn apabila diterapkan sebagai produk adalah:

a) Risiko tidak terbayarnya utang nasabah.

b) Risiko penurunan nilai aset yang ditahan atau rusak.

c) Risiko pemalsuan barang gadai. ${ }^{17}$

\section{Sistem Gadai Emas Syariah}

Sistem adalah jaringan kerja dari prosedur-prosedur yang saling berhubungan, berkumpul bersama-sama untuk melakukan suatu kegiatan atau menyelesaikan suatu sasaran tertentu.Prosedur adalah suatu urutan operasi tulis menulis dan biasanya melibatkan beberapa orang di dalam satu atau lebih departemen yang diterapkan, untuk menjamin penanganan yang seragam dari transaksi-transaksi bisnis yang terjadi. Urutan yang tepat dari tahapan-tahapannya yaitu apa, siapa, kapan, dan bagaimana.

Suatu sistem yang baik harus mempunyai tujuan dan sasaran yang tepat karena hal ini akan sangat menentukan dalam mendefinisikan masukan yang dibutuhkan sistem dan juga keluaran yang dihasilkan. Sistem juga merupakan kumpulan elemen-elemen yang saling terkait dan bekerja sama untuk mencapai tujuan yang diinginkan. ${ }^{18}$

\footnotetext{
${ }^{16}$ Bank dan Lembaga Keuangan Syariah, h. 402-408.

${ }^{17}$ Fiqh Ekonomi Syariah, h 297

${ }^{18}$ Andi Kristanto, Perancang Sistem Informasi dan Aplikasinya, (Yogyakarta: Gava Media, 2018), h. 1.
} 
Pada umumnya, masyarakat telah lazim menjadikan emas sebagai barang berharga yang disimpan dan dijadikannya untuk objek rahn (gadai) sebagai jaminan utang untuk mendapatakan pinjaman uang. Yang dimana, ongkos dan biaya penyimpanan barang yang dilakukan berdasarkan akad ijarah ditanggung oleh pengadai yang besarnya didasarkan pada pengeluaran yang nyata diperlukan dan tidak boleh ditentukan berdasarkan jumlah pinjaman. ${ }^{19}$

Konsep gadai emas hampir sama seperti menggadaikan BPKP atau barang elektronik lainnya. Bedanya, jaminan yang diberikan berupa perhiasan atau emas batangan. Jika emas sudah memenuhi syarat, maka peminjam akan memperoleh uang sesuai nilai taksir pinjaman.

Secara umum, syarat untuk gadai emas di Pegadaian meliputi KTP/SIM/Paspor yang masih berlaku, barang jaminan berupa emas perhiasan, emas batangan, atau emas lantakan. Syarat lainnya disesuaikan dengan model pembiayaan yang diambil.Untuk gadai emas, rahin bisa gunakan Rahn, Rahn Hasan, Rahn Fleksi, dan Rahn Tasjily. Berikut ketentuan khususnya, yaitu:

a) Rahn melayani pembiayaan dengan jangka waktu 4 bulan yang bisa diperpanjang. Selain syarat tersebut diatas, rahin harus menandatangani Surat Bukti Rahn (SBR)

b) Rahn Hasan. Rahn Hasan merupakan pinjaman tanpa biaya jasa dengan jangka waktu 60 hari.Untuk mengikuti pembiayaan ini, rahin hanya perlu melampirkan KTP/SIM/Paspor.

c) Rahn Fleksi. Pembiayaan gadai dengan jangka waktu mulai dari 15,30 dan 60 hari. Untuk mengikuti pembiayaan ini, rahin hanya perlu menyerahkan KTP/SIM/Paspor.

d) Ranh Tasjily. Rahn Tasjily yaitu jaminan dalam bentuk barang atas utang, dengan kesepakatan bahwa yang diserahkan kepada murtahin hanya bukti sah kepemilikannya, sedangkan marhun tetap dalam penguasaan rahin. ${ }^{20}$

Pegadaian syariah merupakan salah satu lembaga keuangan lainnya yang sudah lama beroperasi di Indonesia. Lembaga ini dimaksudkan untuk memberikan pinjaman-pinjaman kepada perseorangan. Lembaga ini sudah cukup lama sejak zaman kolonial, yang sangat dibutuhkan oleh rakyat kecill Pinjaman yang diberikan didasarkan pada nilai barang jaminan yang diserahkan, tujuan lembaga ini adalah mencegah rakyat kecil yang membutuhkan pinjaman agar tidak jatuh ke tangan para pelepas uang yang dalam pemberian pinjaman mengenakan bunga (rentenir). ${ }^{21}$

\footnotetext{
${ }^{19}$ Darsono, dkk, Perbankan Syariah Di Indonesia: Kelembagaan dan Kebijakan serta Tantangan Ke Depan, (Jakarta: Rajawali Pers, 2017), h. 236.

${ }^{20}$ Sahabatpegadaian.com, diakses pada tanggal 22 Maret 2019 pukul 21.13.

${ }^{21}$ Julius R. Latumaerissa, Bank dan Lembaga Keuangan Lain: Teori dan Kebijakan, (Jakarta: Mitra Wacana Media,2017), h. 595
} 
Pegadaian syariah juga dapat membantu masalah ekonomi di negara Indonesia dengan sistem yang cepat dan berjangka pendek.Dan pegadaian syariah juga memberikan keamanan bagi semua nasabah.Pegadaian syariah sebagai salah satu solusi yang muncul di tengah kegelisahan masyarakat terhadap praktikpraktik penipuan.Secara konsep pegadaian syariah terfokus pada mekanisme kepengelolaannya. Secara umum ciri dari pegadaian adalah transaksi dari pemilik dana (modal) dengan pemilik barang.

Pada dasarnya, konsep pegadaian syariah yang dimaksud dapat dilihat dari dua aspek. Pertama, kebutuhan konsumtif. Kedua, kebutuhan produktif. Adapun latar belakang munculnya sistem syariah secara umum tidak terlepas dari mekanisme sistem konvensional yang menggunakan konsep bunga, sebab dengan konsep bunga yang diterapkan dalam pegadaian konvensional dapat dikategorikan sebagai riba dan hal ini dilarang oleh Islam seperti pada dalil Al-Quran QS. AliImran (3) : 130.

Berdirinya pegadaian syariah yaitu bekerjasama dengan Bank Muamalat Indonesia.Karena Bank Muamalat Indonesia sendiri masih belum mempunyai keahlian manajemen dalam bidang ahli menaksir barang, sementara pegadaian sudah mempunyai ahli penaksir barang. Sifat usaha pegadaian pada prinsipnya menyediakan pelayanan bagi kemanfaatan umum sekaligus memupuk keuntungan berdasarkan prinsip pengelolaan. Oleh karena itu, pegadaian mempunyai tujuantujuan pokok seperti yang dicantumkan dalam PP No. 103 tahun 2000 sebagai berikut:

a) Turut meningkatkan kesejahteraan masyarakat terutama golongan menegah kebawah melalui penyediaan dana atas dasar hukum gadai, dan jasa bidang keuangan lainnya berdasarkan ketentuan peraturan perundang-undangan yang berlaku.

b) Turut melaksanakan kebijakan dan program pemerintah di bidang ekonomi dan pembangunan nasional pada umumnya melalui penyaluran uang pinjaman kepada masyarakat atas hukum gadai.

c) Mencegah dan memberantas praktik pegadaian gelap, ijon, dan pinjaman tidak wajar lainnya ${ }^{22}$.

\section{Barang Jaminan Pada Gadai Syariah}

Jenis barang yang dapat diterima sebagai barang jaminan, antara lain:

a) Barang-barang perhiasan, yang dibuat dari emas, perhiasan perak, platina, baik yang berhiaskan intan ataupun mutiara.

b) Barang-barang elektronik seperti laptop, TV, Kulkas, dan lain sebagainya.

c) Kendaraan seperti sepeda motor ataupun mobil.

\footnotetext{
${ }^{22}$ Lembaga Perekonomian Islam, h.273.
} 
d) Barang-barang rumah tangga seperti mesin.

e) Barang-barang lain yang dianggap bernilai. ${ }^{23}$

\section{METODOLOGI PENELITIAN}

Pendekatan yang digunakan dalam penelitian ini adalah penelitian kualitatif desktiptif. Penelitian kualitatif deksirptif merupakan prosedur penelitian yang menghasilkan data deskriptif berupa ucapan atau tulisan dan perilaku yang dapat diamati dari orang (subyek) itu sendiri. ${ }^{24}$ Peneliti membuat gambaran tentang objek yang telah diteliti dengan cara sistematis tentang faktafakta yang diperoleh yang berkaitan dengan penelitian.

\section{PEMBAHASAN}

\section{Penerapan Sistem Gadai Emas pada Pegadaian Kantor Cabang Probolinggo}

Gadai emas merupakan salah satu produk unggulan pada PT Pegadaian syariah kantor cabang kota probolinggo. Gadai emas merupakan pemberian dana kepada nasabah dengan cara pembiayaan gadai yang dapat memenuhi kebutuhan untuk dengan mudah, cepat dan sesuai dengan syariah, cepat prosesnya, aman penyimpanannya.

Proses pengadaian emas pada kantor cabang probolinggo harus melaui proses tahapantahapan berikut:

a. Tahap awal pengajuan pembiayaan:

1) Rahn menyerahkan marhun sebagai barang jaminan

2) Rahn mnyerahkan fotocopy KTP/SIM/Paspor

3) Rahn mengisi formulir pengajuan pinjaman dan menandatanganinya.

4) Konfirmasi nasabah dengan mnyatakan kesesuaian pengajuan yang sudah

disepakati. Adapun waktu pembiayaan selama 4 (empat) bulan, akan tetapi apabila nasabah tidak dapat menebus akan dikenakan biaya sewa modal.

b. Tahap penaksiran emas sebagai barang jaminan. Tahap penaksiran gadai emas ini dilakukan dengan menguji dan meneliti emasnya. Langkah-langkah yang dilakukan untuk meneliti sebagai berikut:

1) Emas di gosok dengan batuuji,

2) Ditetesi air

3) Ditimbang

${ }^{23}$ Bank dan Lembaga Keuangan Syariah, h.409-424

24 Arif Furchan,Pengantar Metodologi Penelitian Kualitatif,(Surabaya: Usaha Nasional,1992),hal. 21 
c. Tahapan pencairan Pembiayaan gadai emas

1) Setelah penaksir menghitung nilai barang jaminan, maka kemudian nilai jaminan disampaikn kepada rahin,

2) Kemudian nasabah menandatangani surat bukti rahn (SSR),

3) Kasir akan memberikan pencairan kepada rahin,

4) Pencairan tersebut dilakukand engan cara cash ataupun transfer ke rekekning rahin.

d. Tahapan jatuh tempo

Jangka waktu tempo pembiayaan gadai emas pada Cabang Pegadaian Syariah yakni selama 4 bulan atau 120 hari dari tanggal awal pembaiyaan.

e. Tahapan Pelunasan

Tahapan pelunasan pembiayaan gadai emas sebagai berikut:

1) Rahin membawa Surat bukti Rahn (SBR) beserta identitas atas nama yang tercantum dalam SBR

2) Rahin menyerahkan sejumlah uang untuk pelunasan

3) Tahap pelunasan ini dapat dilakukan sewaktu-waktu dengan penghitungan $M u ' n a h$ selasa masa pinjaman

4) Pinjaman dapat diangsur oleh rahin

\section{Kendala yang di hadapi oleh Pegadaian Syariah Pada Penerapan System Gadai Emas} Kantor Cabang Kota Probolinggo.

Dalam menerapkan sistem gadai emas, tentu terdapat kendala-kendala yang dihadapi oleh pegadaian syariah kantor cabang kota probolinggo. kendala tersebut diantaranya:

a) Pihak pegadaian mengalami kesulitan untuk menghubungi nasabah yang sudah jatuh tempo masa pembiayaannya. pada umumnya, nasabah akan mengganti nomor hp mereka ketika mereka tidak dapat melunasi pembiayaan sesuai jadwal yang sudah ditentukan.

b) Komplain nasabah atas barang yang di lelang oleh pihak pegadaian. Pelelangan barang akan dilakukan oleh phak pegadaian atas barang yang dijadikan jaminan atas pembaiyaan gadai emas. meskipun sudah tertera pada surat perjanjian pembiayaan, nasabah seringkali komplain atas barang jaminan yang akan dilelang oleh pihak pegadaian. 


\section{PENUTUP}

\section{Kesimpulan}

Dari penelitian yang sudah dilakukan, dapat disimpulkan bahwa gadai emas merupakan salah satu produk pegadaian yang dimiliki oleh perusahaan pegadaian syariah kantor cabang probolinggo. dalam sistem gadai emas ini, pihak pegadaian mnyediakan dana yang kemudian disalurkan kepada nasabah yang membutuhkan dengan menggunakan emas sebagai jaminannya.

Berikut proses tahapan pada gadai emas di perusahaan pegadaian kantor cabang kota probolinggo, antara lain:

1. Tahap awal pengajuan pembiayaan

2. Tahap penaksiran emas sebagai barang jaminan

3. Tahapan pencairan pembiayaan

4. Tahapan Jatuh tempo

5. Tahapan Pelunasan

Sedangkan Kendala yang dihadapi oleh pihak pegadaian sering kali terjadi pada saat jatuh tempo akan tetapi nasabah belum melunasi sesuai dengan jangka waktu yang sudah ditentukan, kendala tersebut diantaranya:

1. Kesulitan utuk menghubungi nasabah karena sudah mengganti no HP yang sudah didaftarkan.

2. Harus menghadapi komplain nasabah atas barang jaminan yang dilelang oleh pihak pegadaian.

\section{Saran}

Untuk peneliti yang akan datang sebaiknya lebih melengkapi data wawacara agar mendapatkan dokumen penjelasan-penjelasan yang lebih detail tentang proses pegadaian emas. 


\section{DAFTAR PUSTAKA}

Kasmir.Manajemen Perbankan, Jakarta:Raja Grafindo Persada, 2003.

Soemitra, Andri. Bank dan Lembaga Keuangan Syariah, Jakarta: Kencana, 2009.

Yusnedi,Achmad. Gadai Syariah, Yogyakarta : Deepublish, 2015.

Harahap,Isnaini. Marliyah, dkk. Hadis-Hadis Ekonomi,Jakarta: Prenada media Group, 2015.

Mustofa,Imam. Fiqih Mu'amalah Kontemporer,Jakarta: Rajawali Pers, 2016.

Rais,Sasli.Pegadaian Syariah: Konsep dan Sistem Operasional: Suatu Kajian Kontemporer:Jakarta: UI-Press, 2005.

Sjahdeini,Sutan Remy. Perbankan Syariah Produk-Produk Dan Aspek-Aspek Hukumnya, Jakarta:Kencana, 2014.

Muslich,Muhammad. Manajemen Risiko Operasional: Teori dan Praktik,Jakarta: PT. Bumi Aksara, 2007.

www.Pegadaiansyariah.co.id diakses pada tanggal 17 Januari 2019. 